\title{
Mulheres palhaças e a política uterina de expansão: entrevista com Karla Concá
} Women clowns and uterine politics of expansion: interview with Karla Concá

Entrevista com Karla Concá concedida à Daiani Cezimbra Severo Rossini Brum ${ }^{1}$ 


\section{Resumo}

Este trabalho apresenta a artista Karla Concá, do grupo As Marias da Graça (RJ), bem como do compartilhamento na íntegra da entrevista cedida por ela para minha pesquisa de doutorado na área de Teatro, que se encontra em andamento. Karla é uma importante figura no contexto da atuação das mulheres palhaças no Brasil, uma vez que atua na área desde os primórdios de seu movimento de expansão, isto é, a partir da década de 1990. Ao narrar sua trajetória, Karla descreve marcos históricos significativos da palhaçaria feita por mulheres no país.

Palavras-chave: Teatro; palhaçaria de mulheres; Karla Concá

\section{Abstract}

This work to present the artist Karla Concá, from the group As Marias da Graça (RJ), as well as the full sharing of the interview given by her to my $\mathrm{PhD}$ research in the area of Theater, which is in progress. Karla is an important figure in the context of the role of female clowns in Brazil, since she has been working in the area since the beginning of her expansion movement, that is, from the 1990s. In describing her trajectory, Karla describes significant historical landmarks in the history of women's clown work in the country.

Keywords: Theater; women's clownery; Karla Concá 


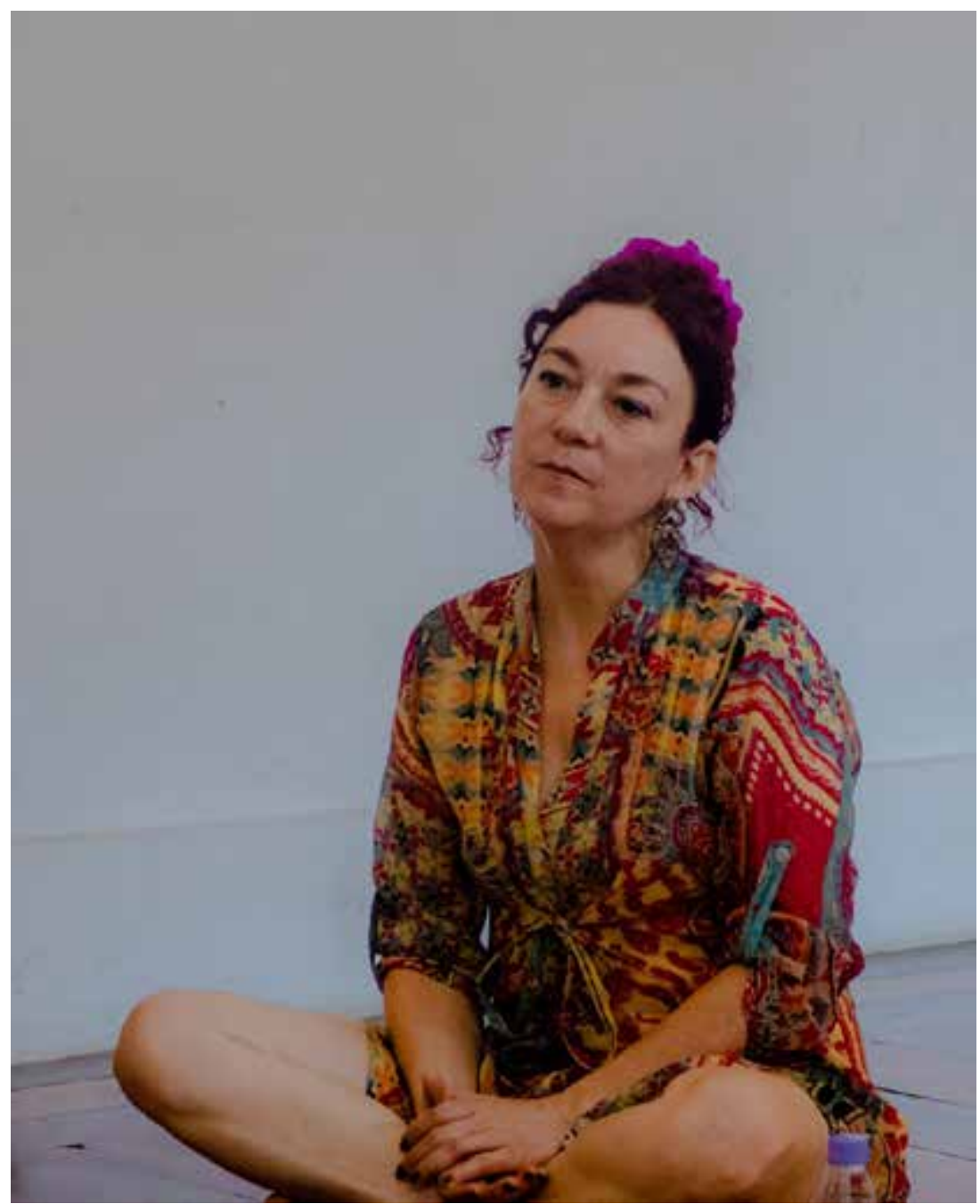

Karla Concá. Foto: Cláudia Bernett

O presente trabalho trata da apresentação da artista brasileira Karla Concá (RJ) e de posterior compartilhamento de uma entrevista cedida por ela para minha pesquisa de doutorado em Teatro, que se encontra em andamento. A entrevista foi realizada de maneira presencial em abril de 2018 e teve como mote central o registro da experiência de Karla Concá, que inaugura a história da palhaçaria feita por mulheres no Brasil. Karla, que nasceu no Rio de Janeiro, atua como palhaça, atriz, pesquisadora, professora de palhaçaria e diretora de espetáculos.

Para Karla Concá e Ana Cristina Borges,

Até os anos 90 era rara a presença de mulheres no universo da palhaçaria. No ambiente circense sua atuação era limitada a números de acrobacia tais como o trapézio, equilíbrio em cavalos ou o contorcionismo, que reforçavam os traços de beleza, feminilidade, graça, leveza e perfeição conferidas à mulher. A incidência de mulheres em papéis cômicos circenses, quando observada, tem natureza secundária quando parte do enredo ou estas estão travestidas de homens com o gênero do palhaço mantido em sigilo para o público. (Cordeiro; Borges, p. 01, 2017)

A arte da palhaçaria, no entanto, conta com uma história de traços milenares, fundamentalmente delineados nos últimos três séculos (Brum, 2017). Ao questionar-se 
sobre esse tardio surgimento das mulheres na arte da palhaçaria, Karla narra sua trajetória de enfrentamento e luta pelo espaço da mulher palhaça. É uma das fundadoras do primeiro grupo de palhaças do Brasil, As Marias da Graça² (RJ), em 1991.

Meu contato com Karla deu-se através de sua vinda à cidade de Florianópolis, onde permaneceu por cerca de vinte dias, em parceria com o espaço/coletivo A Morada Cênica ${ }^{3}$. Karla ministrou uma oficina de direção de números para cinco palhaças residentes da cidade, que resultou na criação do espetáculo Manicômicas. Tive a oportunidade de participar da oficina e de compor o elenco do espetáculo. Chamou-me a atenção, desde o primeiro dia de encontro com Karla, sua capacidade e vontade de valorizar os diversos materiais apresentados pelas palhaças, bem como a maneira cômica como ela narrava suas próprias experiências.

Observando a partir das entrelinhas e questionando-se sobre o porquê de cada palhaça realizar determinados gestos, Karla potencializava as ações oferecidas, de modo a assumir uma postura que, nesta entrevista, ela intitulou de "política uterina de expansão". Isto é, a artista optou por trabalhar na perspectiva de expandir o universo de experiência das mulheres, transformando-o em ação cênica e estratégia de autoconhecimento. Como artista e professora, Karla abriu mão de roteiros pré-estabelecidos de comicidade, enraizando-se em um riso que parte das experiências e questões que permeiam cada palhaça.

Essa perspectiva corrobora a afirmação de Melissa Caminha, segundo a qual: "Las mujeres cuentan sus historias a partir de sus experiencias e vivencias como mujeres, como cuerpos situados y construidos históricamente según discursos, fuerzas y prácticas de significación específicas y contextuales" (Caminha, p. 29, 2015). Olhar de tal forma para os aspectos de cada mulher é perceber em que contextos sociais, étnicos, econômicos e de orientação sexual elas estão situadas. Melissa afirma, ainda, que: "O riso é uma ferramenta feminista para desestabilizar as normas e construir realidades alternativas ao sistema patriarcal." (Caminha, p. 80, 2015).

Karla faz eco a esse pensamento e afirma, nesta entrevista, que, quando ela e as Marias da Graça tomaram consciência dos aspectos feministas da palhaçaria que estavam realizando, decidiram se aprofundar no compartilhamento de ações entre mulheres, uma vez que o sistema patriarcal as excluía do mercado de trabalho. Foi nesse contexto que surgiu o primeiro festival de mulheres palhaças do Brasil, o "Esse Monte de Mulher Palhaça". Criado em 2005, o Festival encaminha-se para a sua oitava edição e é o principal responsável pela visibilidade internacional das mulheres palhaças do Brasil, oferecendo ainda um espaço/tempo de acolhimento para palhaças de outros países. Desse modo, as conexões desenvolvidas por Karla Concá nos ligam de maneira direta à trajetória da palhaçaria feita por mulheres no Brasil. Segue a entrevista concedida por Karla Concá para a minha pesquisa de doutorado.

\footnotetext{
${ }^{2}$ O grupo As Marias da Graça foi fundado em 1991, no Rio de Janeiro. Trata-se do primeiro grupo de mulheres palhaças do Brasil e atualmente é composto pelas palhaças Karla Concá, Geni Viegas, Vera Ribeiro e Samantha Anciães.

${ }^{3}$ A Morada Cênica é um espaço de residência e trabalho do coletivo formado pelas artistas Márcia Gonzaga, Maysa Carvalho, Calini Detoni e Daiani Brum. No espaço, que está situado em Florianópolis, no bairro Campeche, realizam-se oficinas, encontros, debates, espetáculos e residências culturais desde 2017.
} 


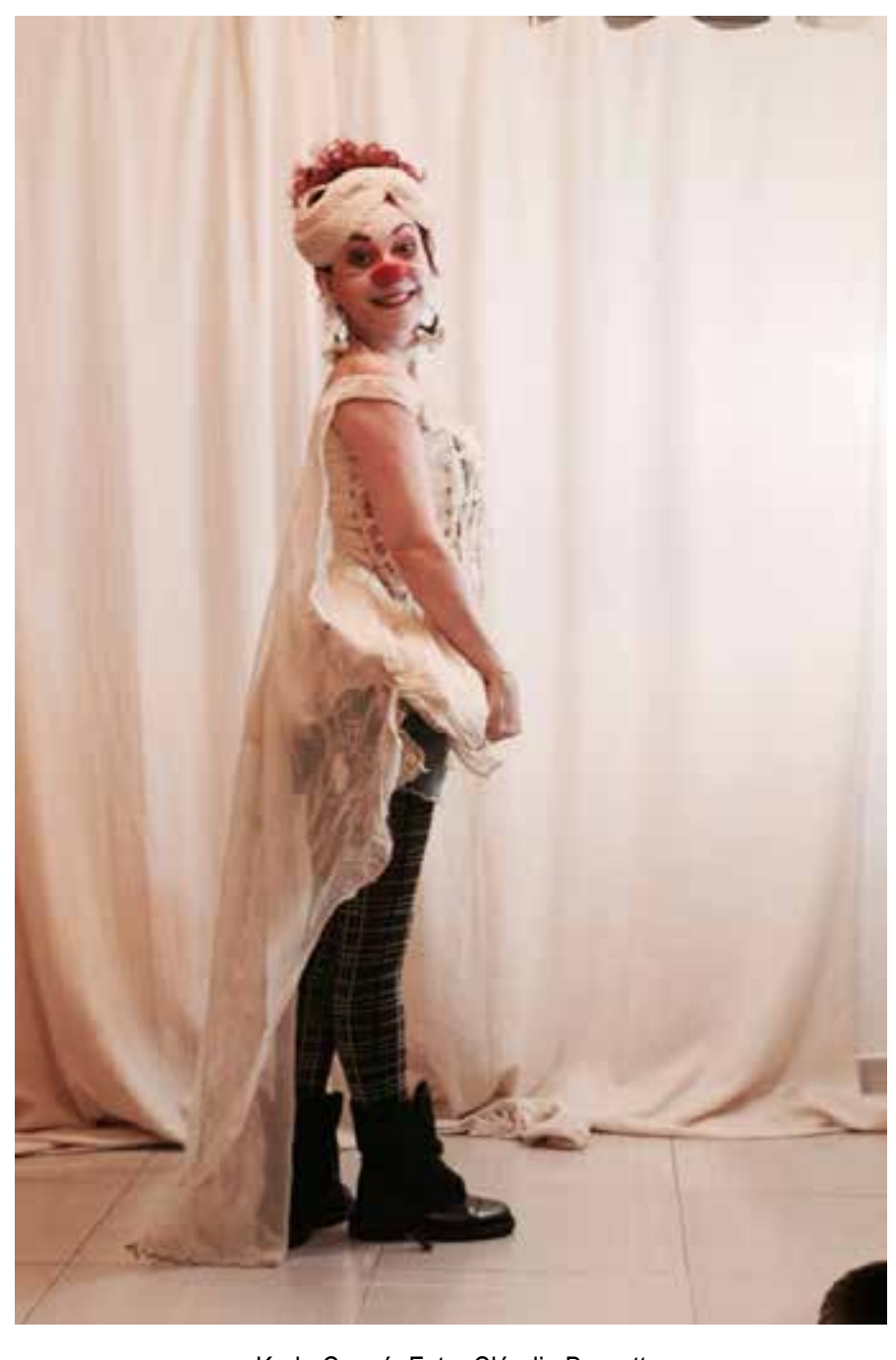

Karla Concá. Foto: Cláudia Bernett

Karla, você poderia me falar um pouco sobre o seu processo como palhaça? Como você visualizou a possibilidade de se inserir neste ofício que, naquele período, era majoritariamente desenvolvido pelos homens?

Vou contar uma história breve sobre como surgiu o grupo [As Marias da Graça], o antes e o depois e como foi que aconteceu. Na verdade eu era atriz, estudava na CAL [Casa de Artes de Laranjeiras], no Rio de Janeiro, sempre falaram que eu era engraçada e eu queria ser atriz dramática. E as pessoas repetiam: "Você é engraçada, você é engraçada, você é engraçada." Até que eu saí da escola e fui fazer um curso de clown. E todo mundo dizia na faculdade que eu tinha que ser clown. Eu não sabia nem o que era isso, ser clown. Aí fui fazer esse curso com outras atrizes também, todas eram atrizes. Eram todas mulheres e tinha um homem, e esse homem desistiu. Eu costumo até dizer que por causa desse homem surgiu As Marias da Graça, porque era o único homem e não deu conta de fazer o curso e saiu. E ficaram somente mulheres. E aí, a gente estudando aquilo com o Guillermo Angelelli, que é um professor argentino muito sensível dentro dessa técnica, dessa arte, e quando acabou o curso cada uma já tinha mais ou menos a sua palhaça, ou o que achava que era isso. $E$ 
a gente era feliz fazendo aquilo. Foram quinze dias e quando acabou eu falei: "Gente, eu não quero fazer outra coisa da minha vida".

Porque achar o meu ridículo e rir dele, fazer o outro rir, para mim, eu estava no paraíso, e aquelas outras mulheres também pensavam daquela maneira. Só que a gente não tinha noção de que estava entrando num terreno proibido. Era só uma vontade de ser aquilo, como sempre é, você sempre tem vontade de fazer aquilo até que alguém chegue e diga que não pode. Então quando a gente começou a trabalhar, fazer o exercício de descobrir a palhaça, acabou a aula e o professor tinha que voltar para casa. E a gente falou para ele: "O que fazemos agora?" E ele falou: "Vão para a rua! Vocês já têm mais ou menos a palhaça de vocês, já tem um estado em que estão se entendendo, vão para a rua".

E assim a gente fez, saímos em sete mulheres para a rua. E a gente ia para a rua, para a feira, andar pelas ruas, pegar um ônibus... um bando de mulheres fazendo isso. Então a gente começou a ouvir os homens na rua falando. Teve um dia que fomos à feira e ouvimos ao chegar na feira: "Ah, vai lavar um tanque de roupa, não tem nada pra fazer?"

Aí a gente pensou: "Que engraçado, né, falar isso!" E a gente ria, a gente não tinha noção nenhuma, nem que a gente estava entrando em um campo masculino, e que, nesse caso, não era nem entrar em um campo masculino, porque os homens da feira não eram circenses, não tinham nem noção disso. A gente estava entrando em um campo da mulher se colocando dentro da sociedade, de alguma maneira. Eram mulheres fazendo alguma coisa que envolvia exposição na rua. Só isso já era o suficiente para um homem te mandar lavar um tanque de roupa. Entendeu? Só de sair de casa para trabalhar você já está invadindo um espaço, um território masculino. Isso é consciência depois de um tempo; naquela época, nenhuma. E assim foi.

Também achavam que a gente era travesti, você imagina, isso foi há vinte e sete anos atrás, 1991 surgiu o grupo. Então você imagina, se hoje ainda existe gente que olha para você e fala: "Olha o palhaço". Você tem que dizer: "É uma palhaça..."

Se hoje ainda existe isso, após toda uma mudança, imagina há vinte e sete anos atrás. Quando sete, não era nem uma, eram sete! Se é uma, ainda disfarça, agora, sete mulheres é impossível disfarçar. Sete mulheres saem, com personalidades completamente diferentes, cada uma era muito diferente da outra, e aí a gente começa a incomodar, mas sem total consciência disso. E dali começa a surgir o grupo As Marias da Graça, e que a gente começa a se fortalecer enquanto coletivo, começa a sair todo domingo. Todo domingo. $\mathrm{E}$ aí os vizinhos começam a encontrar com a gente na rua. No domingo, até chegar ao Aterro [do Flamengo], lugar bem específico no Rio de janeiro, espaço de lazer, a gente passava pelos vizinhos, normalmente os homens tomando suas cervejas, aquelas mulheres que estão passeando com seus filhos. Então fomos criando o nosso público. Quando passávamos, as pessoas já estavam nos esperando. E aí no Aterro começou a se criar uma expectativa. As pessoas começaram a parar para assistir a gente. Só que a gente não tinha nada (risos). Éramos apenas sete mulheres, a gente não tinha ideia do que estava formando.

Porque a gente não era nada. Éramos apenas sete mulheres querendo se divertir. A gente não tinha essa ideia de que estava formando o grupo, que queria ser um grupo. Não, a gente estava ali, se divertindo para ver o que era. Na verdade era apenas um reflexo daquela frase que o professor falou: "Vão para a rua." Colocar as nossas 
palhaças na rua era o que a gente estava fazendo, então começou a parar gente para assistir. E aí a gente falou: "Ué..."

Parava gente, a gente andava, ia fugindo das pessoas. E com essa história, nesses lugares de lazer, no Rio de Janeiro, tem sempre um jornalista, sempre alguém cobrindo. Aquela coisa: "Hoje, domingo de sol no Rio de janeiro, famílias passeando..." $\mathrm{E}$ aí começou a calhar de as pessoas fazerem matérias com a gente. $\mathrm{E}$ realmente, a gente era um estranhamento dentro daquilo ali, já era uma coisa esquisita. Era um cenário que sempre era a mesma coisa e apareciam sete palhaças fazendo nada. $A$ gente começou a ter matérias no jornal, e isso começou a chamar a atenção das pessoas. E cada vez mais as pessoas começavam a ir ao Aterro, esperando aquele grupo que alguma hora ia chegar, até que a gente pensou em fazer um número, já estava demais, não tinha nada para mostrar. Era um grupo só de mulheres, e falamos: "Sobre o que que a gente vai falar?"

A gente tinha uma das palhaças cujo traje era de noiva, que é um signo muito forte para a mulher, em um grupo só de mulheres, e a gente criou uma cena de casamento. $E$ aí, o que é interessante, pensando que isso foi há 27 anos, quando um grupo de palhaças veio com uma cena de casamento, a partir de uma questão que a gente tinha no grupo, não se tratava de pegar uma gag ${ }^{4}$, ou uma cena pronta, um efeito cômico pronto. A gente não foi no passado para pegar nada. A gente pegou o que tinha naquele momento, que era uma questão das mulheres. Então a gente não foi beber em uma fonte masculina. As Gags e os efeitos cômicos são de fontes masculinas, você olha para trás, eram homens que faziam aquilo. Então não adiantava a gente buscar referências que não nos representasse, éramos mulheres fazendo aquilo.

Então a gente começa a se colocar neste lugar do gênero, mesmo que de maneira inconsciente. Então eu sempre digo que as Marias da Graça surgiram da nossa própria necessidade de falar sobre um tema que era nosso. Nós não fomos beber em uma fonte que já existia. Nós criamos a nossa própria fonte de sobrevivência. Então, quando eu falo que nós, palhaças, estamos criando nossas próprias trajetórias, é nisso que eu penso, nós estamos criando mesmo. As nossas necessidades são completamente diferentes das necessidades dos homens, diferentes das necessidades de uma gag já pré-estabelecida, que normalmente são desenvolvidas por palhaços homens, são, na maioria das vezes, altamente machistas, colocam a mulher em uma vulnerabilidade emocional enorme.

A mulher que está assistindo, muitas vezes, se sente violentada, por que as gags são sempre batendo, são sempre com um porrete batendo na mulher, ou correndo atrás da mulher, sempre colocando a mulher em uma situação de inferioridade, sexualização e submissão. Então nós, mulheres, há vinte e sete anos atrás, criamos um número a partir de uma palhaça nossa e percebemos estar mexendo neste lugar da dramaturgia masculina, isso sem a menor consciência.

E aí a gente cria este número do casamento e é um sucesso enorme. Começam os convites para a gente se apresentar. Até que a prefeitura do Rio de Janeiro resolve contratar a gente para a inauguração do Arpoador, um parque no Rio onde tinha uma

${ }^{4}$ Gag é um termo que designa a construção de uma cena ou efeito cômico pré-determinado. Na dramaturgia circense, por exemplo, existe um vasto repertório de gags ou situações cômicas que podem ser remontadas ou repetidas por diversos palhaços e palhaças. 
praça. Então fizemos o espetáculo "Tem areia no maiô", que a gente faz até hoje e é sobre mulheres, mulheres na praia. Novamente entramos com o nosso material, a partir das nossas circunstâncias, somos mulheres, somos cariocas, temos praia, jogamos frescobol nas praias, vendemos biscoito e sorvete na praia, que é esse universo das cariocas na praia. Então a gente chamou o Rui Cortez para fazer os nossos figurinos, o Beto Brown para dirigir, fizemos maiôs incríveis que nós temos até hoje, e montamos o "Tem areia no Maiô", que ficou um escândalo dentro desse cenário, porque novamente a gente quebra com vários padrões predeterminados dentro de uma dramaturgia feminina.

Aí começam a vir várias críticas de várias pessoas assistindo, e aí eu lembro muito que a gente teve uma crítica da Lúcia Cerrone, uma crítica de teatro infantil na época. A gente acabou entrando no horário infantil porque também tinha isso, ninguém sabia onde encaixar a gente. Eu só fui entender a crítica anos depois, naquela época a gente não tinha dimensão. E a crítica dela dizia assim: "Como diziam os Dzi Croquettes, nós não somos homens, nós não somos mulheres, nós somos gente como vocês. As Marias da Graça inauguram uma nova linguagem".

Quando eu lembro dessa crítica de vinte e sete anos atrás, eu penso que foi muito forte uma crítica de teatro escrever isso. Ali ela entra com a gente neste lugar do híbrido, neste lugar do fronteiriço. E a gente não tinha entendido ainda o que a gente era. A gente só foi entender na pele. Na carne, eu tenho a experiência da carne. É o que eu vivi, eu faço parte desta história. A gente estava entrando em uma estrutura que era muito sólida, muito rígida, que era uma estrutura de palhaço. Quando você entra nisso não sendo aquilo que se espera que seja, você rompe com aquilo, você mexe. Desestruturar para algumas pessoas pode ser desesperador, porque quando você desestrutura alguém, a pessoa perde aquele chão e tem que recomeçar. Algumas pessoas estão rígidas, difícil encontrar pessoas que queiram recomeçar alguma coisa. Então a gente estava mexendo nessa estrutura.

Nós não tínhamos ideia do tamanho deste iceberg, e nem de quão fundo ele era. Quando fomos aprofundando, começaram a surgir as crises, e a primeira foi a sustentabilidade do grupo. A gente percebeu que não era chamada para trabalhar e não entendíamos o porquê. Levamos dez anos nesta autocombustão. Já éramos reconhecidas enquanto grupo, mas não tínhamos ainda o mesmo respeito de acordo com a nossa fama. A gente era muito conhecida, mas não era respeitada no nosso meio, por parte dos palhaços, dos organizadores de festivais, e a gente não trabalhava. Nunca chamavam a gente. Começamos a questionar isso. Percebemos que as mulheres não eram chamadas para participar dos festivais, não era só com a gente. Não havia mulheres. Estava começando esta história de mulheres.

Neste momento acontece um rompimento no grupo, duas pessoas saem do grupo, que, de sete, foi para seis, [depois] para cinco e, por fim, saem duas pessoas importantes do grupo, e ficamos em três: eu, Geni e a Vera. E nesse momento de crise e caos, ou a gente terminava ou ressignificava o grupo. $O$ caos é muito importante para isso, porque ele é determinante na sua vida: ou ele te faz desistir ou faz com que você ressignifique as situações. No nosso caso a gente ressignificou, e para isso tivemos que pedir ajuda. 
Procuramos ajuda de uma pessoa que deu um valor que a gente nem sabia que tinha. Encontramos a Cléia, da FASE [Fundação de Atendimento Socioeducativo], que era uma ONG que trabalhava com grupos populares. E quando a gente foi procurar ela, a gente nem sabia se ia ser aceita, indicaram e nós fomos. Quando chegamos lá, ela falou assim: "Ah, eu topo trabalhar com vocês." A gente achou aquilo estranho, ela topou na hora. E perguntamos o porquê. E ela disse que era por sermos um grupo social. E nós pensamos, como assim um grupo social? E ela começou a explicar: "Quantas palhaças existiam em 1991? vamos fazer esta linha do tempo de vocês, vamos pesquisar. Quantas palhaças existem agora em 2001?" Aí a gente viu que tinha triplicado o número de palhaças em dez anos. Então ela falou: E vocês acham que quem conquistou isso? Quem abriu a porta para esta profissão da palhaçaria das mulheres no Brasil?" E a gente falou: "Fomos nós?" Ela disse: "É. E isso é uma função social".

Abriu-se o mundo na nossa frente, tanto que quando as pessoas me perguntam se eu faço projeto social eu digo que eu sou o próprio projeto social (risos). Um projeto social de sobrevivência e resistência. Quando ela fala isso para a gente, nós começamos a entender o que estávamos fazendo e onde tínhamos mexido. $\mathrm{E}$ começa a questionar o próprio grupo. Porque nós mesmas, dentro do próprio grupo, reproduzíamos algumas estruturas opressivas. Por exemplo, durante o processo do "Tem areia no maiô", duas mulheres engravidaram, e a gente tinha que parar várias vezes para amamentar as crianças. $E$ tinha mulheres no próprio grupo que ficavam incomodadas quando a gente parava para amamentar.

Até, no grupo, uma mulher se incomodava com a outra a partir de uma questão que era feminina. E aí está uma das diferenças entre um grupo misto e um grupo só de mulheres. E aí a gente começa a ver, enquanto Marias da Graça, que precisávamos nos respeitar enquanto um grupo de mulheres atuando dentro da arte. E nesse novo momento do grupo, a partir destas compreensões, nós nos tornamos as Marias da Graça que nós somos hoje. Até o ano de 2000 nós não tínhamos nenhuma ação feminista. A gente só incomodava pelo fato de existir. E tem uma diferença entre só incomodar por existir e ter a consciência disso, por que você se fortalece a vai fundo na missão de incomodar. Então as Marias da Graça, a partir de 2001, começam a incomodar por que existem, e conscientes de que incomodam. E aí o incômodo passa a ser proposital e consciente. E assumimos a missão de dar voz a esse bando de palhaças.

Já que a gente já abriu a porta nesse caminho todo, vamos dar consciência para essas mulheres. A gente descobre isso tudo durante o trabalho com a Cléia e aí ela fala uma coisa muito interessante que eu falou muito nos grupos e rodas de mulheres. A Cléia falava assim: "Não vai adiantar vocês procurarem suporte em lugares patriarcais, porque eles não vão dar suporte. Não é do interesse deles ter esse olhar para as mulheres, por que o sistema é patriarcal. Vocês têm de procurar ajuda em lugares que são de mulheres. O apoio de vocês está ali. A verba de vocês está ali".

Então fomos atrás de fundos para mulheres. Por isso que é tão importante ter mulheres na política, porque, através da participação delas, a política para mulheres vai se fortalecer. A gente começa quando tem a Lucélia Freire no Ministério como Ministra das Mulheres, a palhaçaria das mulheres deu um upgrade. A gente consegue chegar até ela, ela consegue enxergar a gente, porque ela é uma ministra de mulheres, então ela consegue enxergar as causas das mulheres, ela consegue investir na gente 
e a gente consegue investir em diversas outras mulheres pelo Brasil, que não têm esse acesso que a gente tem.

Então, a partir de 2011, a gente começa a usar a nossa fama, vamos dizer, entre aspas, em prol das mulheres, mas agora com consciência. Então o primeiro fundo de apoio que nós conseguimos foi de um grupo americano que apoiava mulheres. Então eles deram uma quantidade em dinheiro para a gente. Conseguimos comprar um computador, virar uma associação, conseguimos existir com CNPJ. É neste momento que a gente vai pedir esse apoio para esse fundo. Era um fundo de mulheres, feito por mulheres, para mulheres. $\mathrm{E}$ a partir daí, quando a gente descobre que as mulheres apoiam mulheres, a gente começa a se fortalecer.

Aí a gente começa a procurar o apoio de mulheres e as mulheres começam a nos apoiar. Então começamos a nos fortalecer enquanto grupo de ação social. Aí a gente é convidada para ir para Andorra [2003], para um Festival de Palhaças. A gente já existia há doze anos na época. E aí a curadora do festival perguntou se existiam palhaças no Brasil. Nós falamos sim, a gente existe há doze anos. Fomos todas para Andorra, fizemos o "Tem areia no maiô". E lá, quando viram a gente, foi um escândalo. Primeiro, ninguém falava com a gente. As brasileiras sentavam isoladas no café da manhã. Ninguém olhava para a nossa cara. Imagina, palhaça no Brasil. Na noite do espetáculo, foi um sucesso. No dia seguinte, quando a gente desceu para o café da manhã, tinha uma mesa reservada com quatro lugares, e era a mesa das palhaças.

E aí a gente começou a ser tratada de uma outra maneira, assim como o Brasil. Existe palhaça no Brasil. Elas não tinham ideia de que já existiam muitas palhaças no Brasil. Quando voltamos para o Brasil, pensamos imediatamente em fazer um festival de mulheres palhaças. E aí a gente resolve fazer o "Esse monte de mulher palhaça" [2005], que é o primeiro festival internacional de palhaças do Brasil. Então a gente trouxe a curadora do Festival de Andorra. Para que que se quer fazer um festival? E isso é uma coisa que eu sempre pergunto para as minhas alunas. Para que a gente quer ser palhaça? É para receber aplausos? Para qualquer coisa é ok, mas é importante sempre ter a consciência do por que de fazer aquilo.

Então, quando fomos fazer o festival, nos perguntamos o porquê de fazer aquilo. Aí começamos a pensar. Para quê? Para dar visibilidade às palhaças do Brasil, para colocar as mulheres em um intercâmbio internacional com as palhaças daqui... A gente começou a citar tudo o que a gente queria para ter um Festival. A partir disso a gente começou a fazer a nossa curadoria. Então o festival não podia banir nenhuma mulher. $O$ festival não pode, por exemplo, assistir vídeos e dizer que uma pode e outra não. Porque não condiz com a missão que o festival prega, que é dar espaço e visibilidade àquelas mulheres que estão à margem. Então a gente organiza a nossa curadoria a partir de uma necessidade que as Marias tinham, de sermos vistas e chamadas para os festivais, trabalhar. Cansamos de reclamar: como não éramos chamadas nunca, fizemos o nosso.

E aí tivemos a liberdade de chamar a mulherada toda e ser felizes. Sair da escassez para ir para a abundância. Sempre, na nossa vida, saia da escassez da reclamação e vai para a abundância do fazer a sua própria história. Quando a gente faz o festival e traz a curadora do festival de Andorra, ela tomou um susto. Percebeu que havia muitas palhaças no Brasil. E aí começamos a trajetória da palhaçaria das mulheres no Brasil em termos de festival. 
Na edição seguinte do festival de Andorra, já não tinha só as Marias da Graça em Andorra, havia mais palhaças que começaram a ir para lá. Lá surge Viena, um Festival em Viena, as curadoras estão lá. No segundo ano do "Esse monte de mulher palhaça", a gente trouxe as curadoras de Viena. Porque era importante trazer as curadoras, são elas que vão movimentar. No ano seguinte, em Viena, mais palhaças brasileiras participam. Aí começa o circuito das palhaças rodando nos festivais internacionais. $E$ aqui começa uma necessidade de se ter também outros festivais de mulheres.

E aí, quando falaram para a gente: "Traz o 'Esse monte' pra cá, traz pro meu estado." E eu me lembro muito de falar para as meninas que o "Esse monte" não tinha que sair do Rio de Janeiro, eu dizia: "Façam festivais nos seus estados. Façam um no Nordeste, vai ser tão rico fazer um festival aí. Faça um no sul." $E$ aí foi incrível porque mulher é um bicho maravilhoso. E aí começaram-se a fazer festivais no Brasil inteiro. Hoje são sete ou oito. Nós temos mais festivais de mulheres palhaças no Brasil do que no mundo. É incrível. Então a palhaçaria das mulheres se alastrou. A partir do nosso festival começa a ter a revista ${ }^{5}$ da Michele [Silveira]. Foi em uma reunião nossa que ela teve essa ideia de mapear as mulheres palhaças do Brasil. As mulheres começam a se juntar e surge a necessidade de fazer o caminho, a nossa trajetória de mulheres palhaças.

Aí vem uma com uma revista [Palhaçaria Feminina], tem um blog para mapear as palhaças do Brasil, surgem pesquisas acadêmicas sobre as mulheres palhaças... Aí começam as criações para facilitar essa abertura de passagem para as mulheres chegarem, saírem da invisibilidade. Teve um ano que foi muito rico. A gente, até mesmo por falta de recursos, decidiu focar no Brasil, mantivemos. Trouxemos duas palhaças internacionais para manter o "internacional" do festival. Foi o ano mais rico do festival, foi quando a gente conheceu a Barrica, foi o ano que a gente conheceu a Odília, a Gena, do Circo Grock. Esse ano foi riquíssimo, porque a gente trouxe essas mulheres que nunca haviam conseguido sair dos seus lugares.

Foi em 2007. Foi quando deu essa virada. No nosso festival, desde então, a gente tem o critério de colocar as brasileiras em horário e dia nobre. Elas ganham sempre sexta, sábado. E a gente sempre bota uma palhaça bem legal, internacional, que chame atenção ou depois ou antes da palhaça brasileira, como uma estratégia para a palhaça brasileira estar sempre em primeiro lugar. O cachê, por exemplo, é o mesmo para todas. Tanto para as internacionais quanto para as nacionais. Contei essa história toda porque ela está muito dentro do que é a trajetória do que é a palhaçaria das mulheres no Brasil.

\footnotetext{
${ }^{5}$ Trata-se da Revista Palhaçaria Feminina, criada por Michele Silveira, a palhaça Barrica, de Santa Catarina. A revista encaminha-se para sua quarta edição, e reúne artigos escritos por mulheres palhaças e/ou que trabalham com assuntos relacionados à comicidade.
} 
Karla, eu te agradeço muito por compartilhar esta história. Dentro desse contexto, ou seja, desde a década de noventa, há um aumento da atuação de mulheres como palhaças, você visualiza hoje diferenças significativas no trabatho das mulheres e dos homens enquanto figuras palhacescas? Isso em diversos aspectos, não apenas no campo estético, mas também social, como quando, por exemplo, você relata sobre uma rede de relações profissionais e afetivas entre mulheres. Pode-se pensar o mesmo em relação aos homens palhaços?

Existem diferenças entre o humor masculino e o humor feminino? Existem. Mulheres riem de coisas de que homens não riem. Mulheres têm as suas especificidades e os homens têm as suas. Com certeza os humores também serão diferentes, no aspecto do fazer. E aí entro nesse campo da dramaturgia. Estou escrevendo até um artigo para a revista da Michele, onde eu falo sobre as diferenças da palhaçaria masculina e da feminina. Essa coisa de a gente não ter uma trajetória, uma referência, no geral foi muito positiva. Isso nos deu uma liberdade que os homens não têm, e muitas vezes é porque eles não querem ter. Ficam lá bebendo anos na mesma fonte. Mas como a fonte deles não nos servia, não nos serve, nós tivemos que criar as nossas fontes, as nossas trajetórias, os nossos caminhos.

E nisso nós estamos também criando a nossa dramaturgia. O que é o palhaço ou a palhaça? É você ampliado, não é um personagem, trata das suas questões, com uma lente de aumento, é uma técnica que gira muito em torno disso. Até aí todo o mundo concorda, tanto homens como mulheres estão de acordo com esse pensamento. Então, a partir do momento em que existe esse pensamento da técnica, e se a técnica parte de quem você é, então você começa a fazer coisa a partir da sua palhaça, das questões que você quer dizer em cada momento.

Então, se você vai em um lugar que já está preestabelecido, da Europa, com as características daquele povo de lá, você pega aquilo e reproduz. No meu ponto de vista, você não está fazendo uma trajetória sua, você está pegando aquilo e refazendo aquilo como é, a não ser que você adapte a técnica ao seu lugar, ao seu ponto de vista. As mulheres fazem isso. Vamos aproveitar a fama de que fazemos discussão de relações, e vamos fazer D.R. Roda de mulheres é o quê? É D.R.

Julgavam-nos como muito agressivas, de falar muito de nós mesmas. Então vamos assumir esse papel. Deixem-nos em paz. Deixem a gente falar da gente. A gente não fica reclamando porque os outros estão fazendo as coisas deles. A gente ouve barbaridades nesse sentido: "Ah, vocês falam só de vocês, vocês vão esgotar o argumento de vocês".

Gente, mulher não se esgota. São argumentos que para a gente não vão influenciar em nada na nossa vida. Pode até atrapalhar, porque se você está chegando agora no caminho da palhaçaria, como o sistema é patriarcal, você precisa de mulheres que te ajudem a enfrentá-lo. É muito importante que tenha mulheres que ajudam outras mulheres a se colocarem em espaços de trabalho. Quando um homem fala uma coisa dessas, se é uma mulher muito jovem em idade e em experiência, ela balança. Então tem que ter uma primata lá, uma velha, que vai dizer: "Olha só, vai no seu caminho, não ouve não. Poupa um pouco o seu ouvido. Vai no caminho que você acredita. Procura orientação de outras pessoas, de mulheres. Não que você não vá ouvir o homem, ouça, mas ouça com cuidado." 
Uma orientação que eu dou é estudar essa nossa história, que é muito recente. Tem muito material já saindo, tem muitas mulheres fazendo coisas pelas mulheres. É um caminho muito novo mesmo. Eu acho que as mulheres, hoje em dia, já conseguem ter este discernimento, de quando você pode pegar uma Gag ou um efeito cômico e trazer para a sua realidade. E até os homens estão tendo que se rever, por que tem espaços que não aceitam mais espetáculos de homens que são muito machistas. Isso está acontecendo atualmente. Já chegou no meu ouvido uma história dessas. Certa instituição falou com um homem. Não seria possível apresentar o espetáculo ali daquela maneira. Um espetáculo que já existia há anos e aquele palhaço teve que mudar a cena final. E isso é muito interessante, teve que mudar o final de uma peça que ele apresentava há anos porque a instituição falou que ele não podia bater em uma mulher. Porque o espetáculo era isso, ele correndo com um porrete para bater em uma mulher. Eu vejo isso como um ganho enorme. O homem entra nesse lugar de mexer na nossa dramaturgia, de mexer no que a gente quer dizer, de dizer que a gente está errada, que vai chegar o momento que a gente não vai mais conseguir fazer nada. E quem está mexendo na dramaturgia do homem são as próprias instituições. Alguns ainda não perceberam isso. É aquilo, você olha muito para as próximas e não olha para você. Então seria interessante que eles olhassem para eles, pois tem muita coisa que eles terão que mudar e não se deram conta ainda.

Por isso que eu venho falando da política uterina. Nós somos uma política uterina. A gente tem este lugar de expansão, a gente se expande. É diferente, por exemplo, da lógica do Augusto e do Branco, que é uma compreensão sobre a palhaçaria que me incomoda muito. E vou te explicar o porquê, por que este enquadro não serve para uma mulher: no meu ponto de vista, eu acho que uma mulher Augusta, quando em TPM, se transforma em uma Branca em dois minutos. Então eu acho que isso serve muito para os homens, por que eles são verticais, aí eu brinco com a ereção masculina, ou ele está Branco, ereto, ou ele está Augusto, sem ereção.

O movimento do homem é sempre vertical, é o Branco e o Augusto. Ele não consegue realmente fazer duas coisas ao mesmo tempo. Ele não consegue expandir, ele consegue fazer aquilo, ou ele está Branco ou ele está Augusto. Nós mulheres, em um dia, nesta lógica, mudamos de Branca para Augusta, Branca para Augusta, Branca para Augusta. Isso nos cabe, mas isso não cabe ao homem. Então eu fico muito triste quando eu vejo que vem uma aluna para mim e fala que alguém, em alguma oficina, a desaconselha de fazer certas coisas por que ela é Branca ou Augusta. Eu falo: Minha filha, você pode fazer o que você quiser, pode ser o que você quiser. Não se defina.

Agora, isso é uma característica da mulher, da dramaturgia da palhaçaria feita por mulheres, porque os homens ficam nesse padrão. Ele é uma coisa ou ele é outra coisa. Depois que você tem filho, você aprende a fechar a geladeira com a bunda enquanto está abrindo o armário com mão e você está com um bebê no colo. $A$ gente é muita coisa, não só Branca e Augusta. Para que eu fale alguma coisa, eu já passei por ela. Eu já me coloquei à prova. A definição é um horror. Se eu acredito em uma definição, eu não terei a ousadia de ir para outro lugar, e isso não serve para mulher, porque mulheres são ousadas. Isso de definir se a mulher é isso ou aquilo não nos cabe. 
Então isso do Augusto e do Branco te leva para um lugar de definição onde você não vai caber. Você até pode ter uma personalidade, mas não ser só aquilo, estar aberta. Se você define uma situação, você não consegue ter a riqueza do jogo. Então eu acho que a palhaçaria das mulheres tem essa política uterina, de expansão. A mulher palhaça não se encaixa. Ela é o que ela quiser ser. Por isso ela incomoda. Para a mulher que vai assistir é também um alívio. Quando você ri de uma palhaça ou de um palhaço, você está se aceitando como você é, o riso é um espelhamento.

E é essa a nossa função social. Você se coloca em jogo, o seu ridículo, a sua dor, para outra pessoa se identificar, e quando ela ri acontece uma cura. Quem dera que os homens tivessem a liberdade de se colocar nessas situações, de falar deles, ao invés de só ficar reproduzindo gags, rodando pratinho e fazendo estas coisas clássicas que eles gostam de fazer e com as quais eu não tenho o menor problema, mas não falem da gente. Quer rodar pratinho, roda pratinho e tá tudo bem. Só não falem da gente. Não fala da nossa bunda. Deixa que da nossa bunda a gente fala. A gente pode falar da nossa bunda, a gente não está mais naquele lugar do príncipe que nos salva, do homem que salva a gente. A gente pode falar da gente mesma, e isso, para alguns, é um perigo.

\section{Karla, eu gostaria de agradecer muito pelas suas falas, são muito ricas na composição deste pensamento tão recente na palhaçaria feita por mulheres. Há algo mais que você queira falar?}

Eu sou uma apaixonada pelo que eu faço, e tenho muito orgulho, tanto da minha trajetória quando da do meu grupo e das mulheres que estão aí sendo palhaças. Não é fácil para as mulheres ser palhaças. E o que eu posso dizer é isso, que desejo força e união entre a gente, que cada vez mais haja rodas de conversas, que eu acho que é um movimento muito bonito que já está acontecendo.

\section{Referências}

BRUM, Daiani Cezimbra Severo Rossini. A atuação de palhaças e palhaços: o hospital como palco de encontros. 2017. 138 f. Dissertação (Mestrado) - Curso de Artes Cênicas, Universidade Federal do Rio Grande do Norte, Natal, 2017.

CAMINHA, Melissa Lima. Payasas: Historias, cuerpos y fuermas de representar la comicidad desde una perspectiva de género. 2015. $371 \mathrm{f}$. Tese (Doutorado) - Curso de Artes y Educación, Artes, Universitat de Barcelona, Barcelona, 2015.

CORDEIRO, Karla; BORGES, Ana Cristina. Palhaçaria feminina: Trajetória de investigação e construção dramatúrgica de espetáculos dirigidos por Karla Concá. in: Seminário Internacional Fazendo Gênero 11 \& 13th Women's Worlds Congress, 13., 2017, Florianópolis. Anais Eletrônicos. Florianópolis: Anais Eletrônicos, 2017. p.1 - 12. Disponível em: <http://www.wwc2017.eventos.dype.com.br/resources/ anais/1503793078_ARQUIVO_7688911.pdf>. Acesso em: 24 abr. 2018.

Recebido em: 08/06/2018

Aprovado em: 09/06/2018 